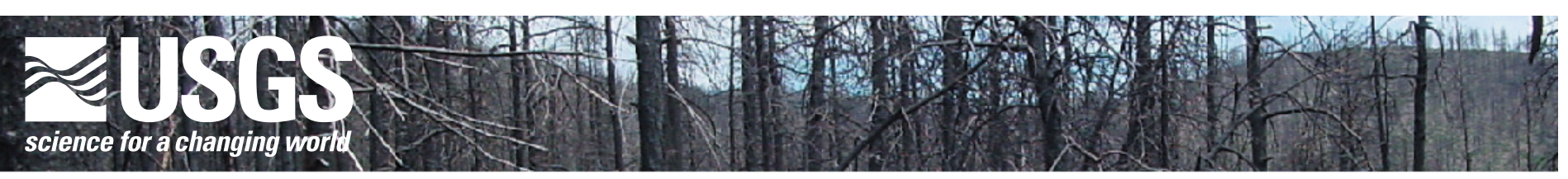

\title{
Integrated Fire Science in the Rocky Mountains
}

\section{Issues}

Fire is an important ecological process that has helped shape western landscapes. Wildfire suppression and other management practices may have altered historic fire regimes in ecosystems adapted to frequent, low-severity fires. Compounding this problem is the encroachment of homes into fire-prone areas.

Fire affects a number of abiotic and biotic components of ecosystems, and has many economic and social ramifications. The full range of consequences, however, remains poorly understood.

To implement sound fire management, managers require improved understanding of fire effects on public lands. Although the importance of fire to ecosystem function is widely recognized, wildfire science has not been fully integrated into management actions.

An interdisciplinary approach is essential to integrate and evaluate tradeoffs among fire management policies and practices.

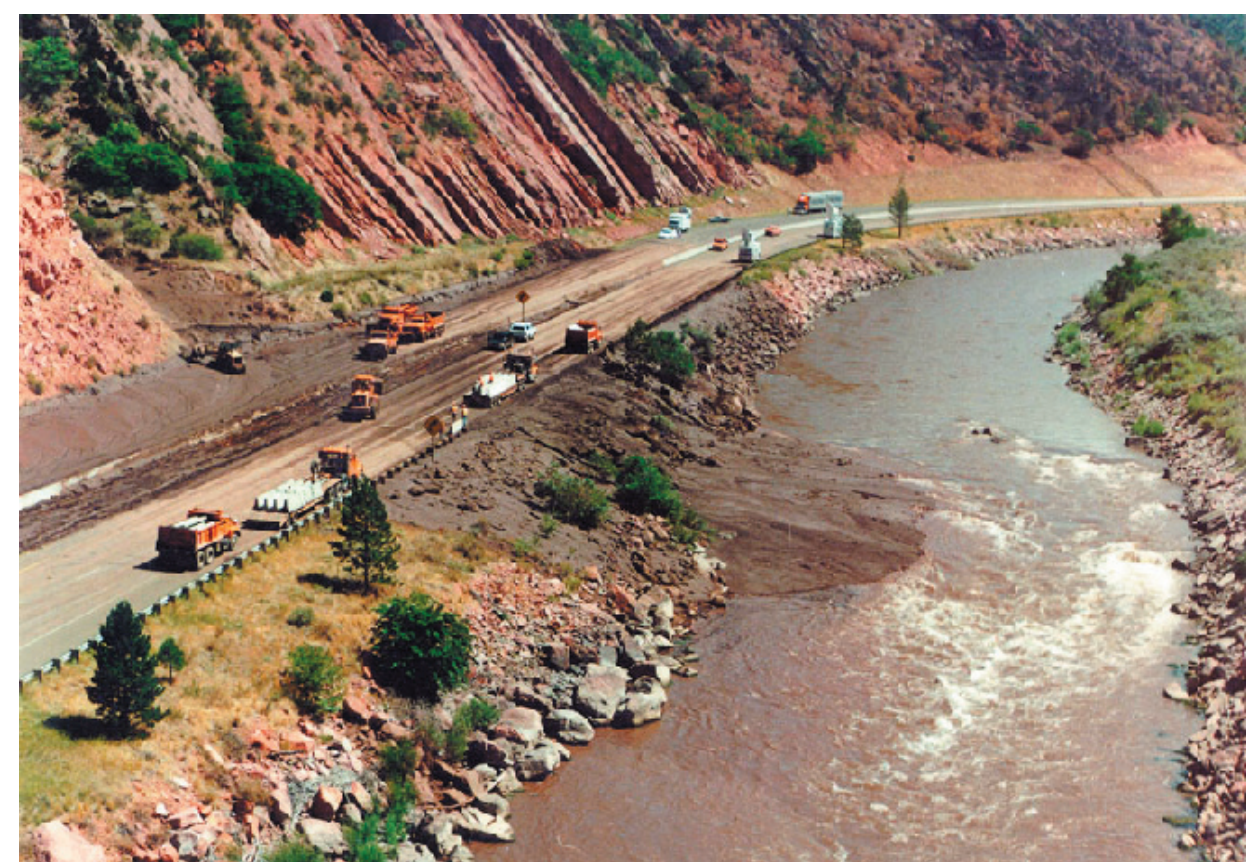

Torrential rains triggered debris flow after Storm King Mountain Fire, Colorado, 1994.

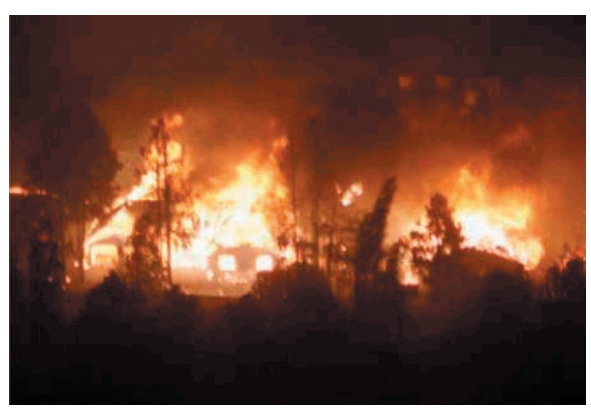

Photo courtesy Los Alamos Volunteer Task Force.

- Evaluate fire management practices: Quantify the ecological effects of wildland fires and the historic role of fire compared to prescribed fire and non-fire treatments. Focal topics include debris flow, erosion, water quality, native and non-native vegetation, avian communities, threatened and endangered species, ecological integrity, and social values and perceptions.

- Evaluate the effects and effectiveness of post-fire rehabilitation: Provide information on the ecological and economic trade-offs of post-fire management by quantifying (1) the effectiveness of post-fire rehabilitation on reducing post-fire hazards (e.g., debris flows and erosion) and (2) the effect of rehabilitation on post-fire communities and landscapes (e.g., native and non-native vegetation, wildlife, and sensitive species).

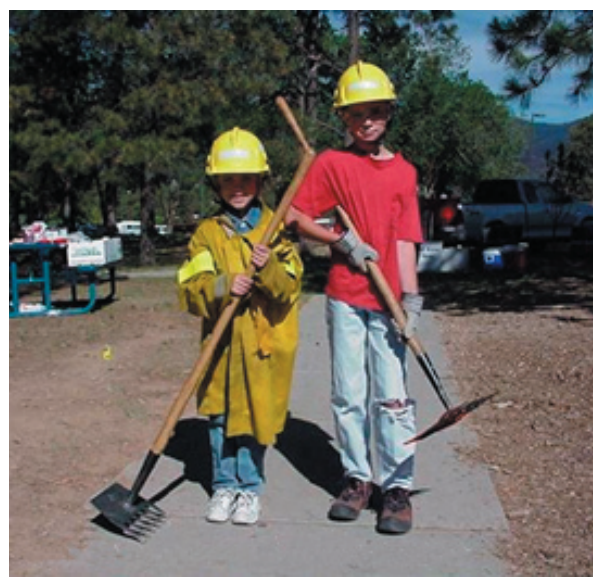

Photo courtesy Los Alamos Volunteer Task Force. 


\section{Capabilities}

The research team's capabilities include integrated scientific evaluation of direct and indirect effects of fire, expert opinion on post-fire hazards and management, and initiation of fire research programs. The research team is available for USGS incident consultation and expertise in response to wildfires.

\section{Partners and Customers}

- National Park Service

- U.S. Fish and Wildlife Service

- Bureau of Land Management

- USDA Forest Service

- Los Alamos National Laboratory

- Native American Tribes

- Universities

- Burned Area Emergency Rehabilitation (BAER) teams

- The Nature Conservancy/North American Fire Learning Network

\section{For more information, contact:}

\section{Natasha Kotliar}

U.S. Geological Survey

Fort Collins Science Center

2150 Centre Ave., Bldg. C

Fort Collins, CO 80526-8118

Tel. 970-226-9446

Fax 970-226-9230

http://www.fort.usgs.gov

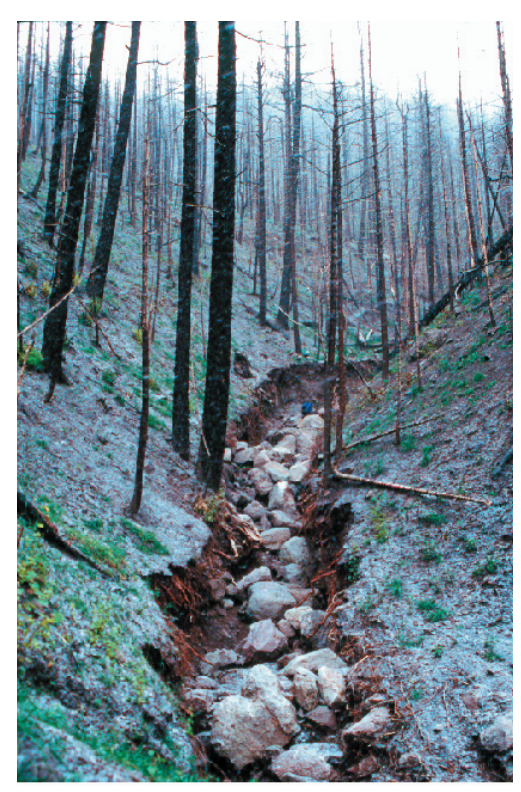

Erosion after a typical thunderstorm with a 1-year recurrence interval (Cerro Grande Fire, New Mexico).

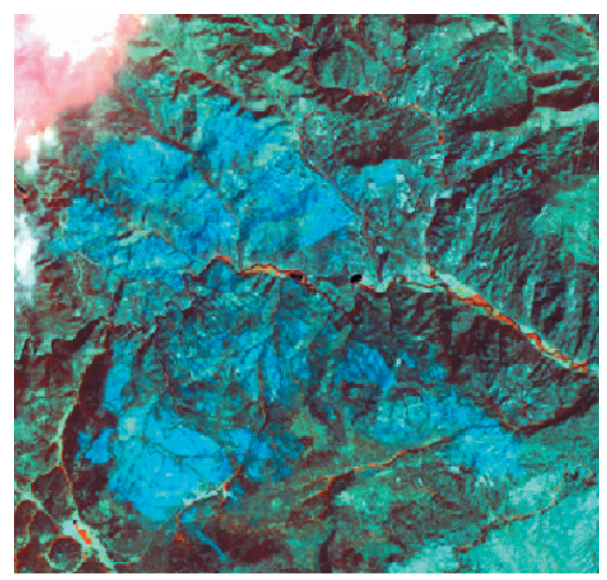

Variations in burn severity (mapped from satellite imagery) are important to understanding changes after fire. Above: Post-fire image of burn scar, Hi Meadow Fire, Colorado.

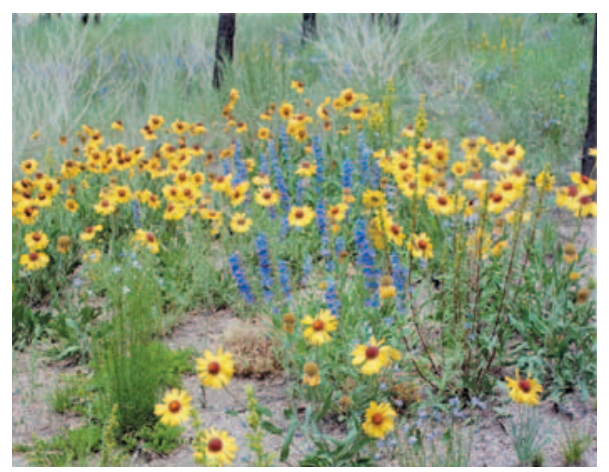

Blanket flowers are early post-fire colonizers in ponderosa pine forests. Photo courtesy Elizabeth Reynolds.

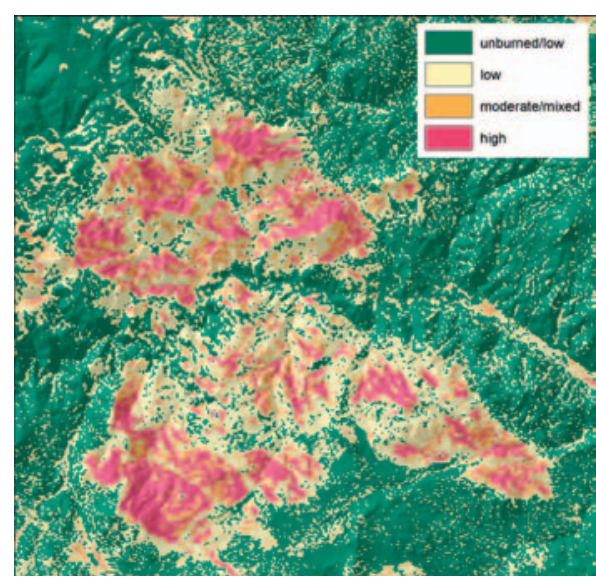

Burn severity map of Hi Meadow Fire, Colorado.

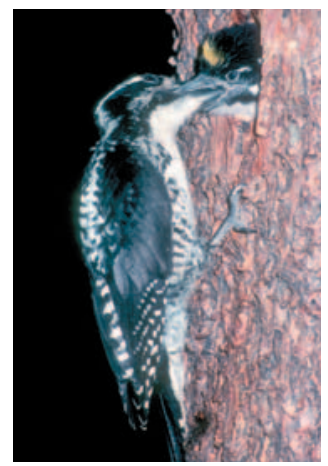

Three-toed woodpeckers are found in burn areas soon after fire, attracted by abundant woodboring beetles.

\section{The Integrated Fire Science Team}

Susan Cannon (Geology, Debris flow) cannon@usgs.gov; 303-273-8604 Geneva Chong (Ecology, Invasives) geneva_chong@usgs.gov; 970-491-5835 Sandra Haire (Landscape Ecology) sandy_haire@usgs.gov; 413-577-3304 John Hogan (Social Science) john_hogan@usgs.gov; 505-662-1963 Carl Key (Landscape Ecology) carl_key@usgs.gov; 406-888-7991 Raymond Kokaly (Remote Sensing) raymond@usgs.gov; 303-236-1359 Lynne Koontz (Economics) lynne_koontz@usgs.gov; 970-226-9384 Natasha Kotliar (Avian Ecology) tasha_kotliar@usgs.gov; 970-226-9446 Deborah Martin (Hydrology, Erosion) damartin@usgs.gov; 303-541-3024 John Moody (Hydrology, Erosion) jamoody@usgs.gov; 303-541-3011 Don Ohlen (Remote Sensing, Mapping) ohlen@usgs.gov; 605-594-6026 Jonathan Taylor (Social Science) jonathan_taylor@usgs.gov; 970-226-9438 